\title{
Load carrying capacity of CFRP strengthened cold formed steel built up box sections
} Nahushananda Chakravarthy ${ }^{1, *}$, Sivakumar Naganathan ${ }^{1}$, Salmia Beddu ${ }^{1}$, Muhammed Harith Akmal ${ }^{1}$, Sreedhar
Kalavagunta $^{2}$, Kamal Nasharuddin bin Mustapha ${ }^{1}$, H. G. Phalguna ${ }^{3}$

${ }^{1}$ Department of Civil Engineering, Universiti Tenaga Nasional, Selangor, 43000, Malaysia

${ }^{2}$ Bentley Systems Pvt Ltd, Singapore, 048622, Singapore

${ }_{3}^{3}$ Mercedes Benz Research and Development India Pvt Ltd, Bengaluru, 560066, India

\section{ARTICLE INFO}

\section{Article history:}

Received 9 July 2017

Received in revised form

15 September 2017

Accepted 15 September 2017

\section{Keywords:}

CFRP

AISI

Cold formed steel

Box section

Beam

\begin{abstract}
A B S T R A C T
This paper presents the experimental investigation conducted on cold formed steel built up box shaped beams strengthened using CFRP. Box shaped cross sections were made of connecting two channel members using screws. The selected beam specimens were $300 \mathrm{~mm}, 400 \mathrm{~mm}$ and $500 \mathrm{~mm}$ in length with screw spacing of $100 \mathrm{~mm}$ and edge distance of $50 \mathrm{~mm}$. Firstly, Single point load bending test were carried out to determine the maximum load, deflection and failure modes for plain sections. Secondly, same bending test were repeated for CFRP wrapped sections to determine the maximum load, deflection and failure mode. The maximum load capacities calculated using AISI specifications are compared with experimental maximum loads which are in good agreement.
\end{abstract}

(C) 2017 The Authors. Published by IASE. This is an open access article under the CC BY-NC-ND license (http://creativecommons.org/licenses/by-nc-nd/4.0/).

\section{Introduction}

Cold formed steel (CFS) are having better advantages over hot rolled steel like thinness, light weight, economical etc. The cold formed steel sections are greater flexibility in cross sectional shapes and sizes. Such a complex shapes leads to challenges in designing of cold formed steel sections (Silvestre et al., 2009). The cold formed steel section ranges from $0.6 \mathrm{~mm}$ to $6 \mathrm{~mm}$ thick. The cold formed steel sections are manufactured by press braking or roll forming operation. In roll forming process series of rollers passes on the steel sections to get the required shapes. This process is carried out in ambient temperature without subjecting into any heat. These cold formed steel sections predominantly available in channel, zed and hat shaped sections. Cold formed steel sections are applicable in decking, roof truss, wall panels, storage racks etc. (Yu, 2000). Thirty years before cold formed steel sections are manufactured with a yield strength of about 200MPa. Nowadays cold formed steel sections are available in the range of 400-600 $\mathrm{MPa}$ yield strength. In Australia maximum yield strength of $1350 \mathrm{MPa}$ cold formed steel members are manufactured recently (Macdonald et al., 2008).

\footnotetext{
* Corresponding Author.

Email Address: nahusha83@gmail.com (N. Chakravarthy) https://doi.org/10.21833/ijaas.2017.010.024

2313-626X/C 2017 The Authors. Published by IASE.

This is an open access article under the CC BY-NC-ND license

(http://creativecommons.org/licenses/by-nc-nd/4.0/)
}

Generally, Hollow steel sections are having varied advantages compared to other sections like load carrying capacity, provide space to fill the concrete in the tube to get greater structural capacity and good aesthetics. Hollow sections are available in square, rectangular and circular shapes (Gardner et al., 2010).

Due to lesser thickness buckling is the common problem in cold formed steel. These cold formed steel beams are subjected to local buckling, distortional buckling, and lateral-torsional buckling (Yu and Schafer, 2006). The behaviour of cold formed steel sections is more complicated than hot rolled steel sections (Kankanamge and Mahendran, 2012). Buckling causes in cold formed section mainly due to low torsional stiffness, the high slenderness and the geometric imperfections (Yu and Schafer, 2003).

In recent days carbon fibre reinforced polymer (CFRP) emerged as a best material in strengthening of a structural members due to its unique characteristics. The external strengthening technique perform better in enhanced load carrying, fatigue, seismic resistance and reduction in buckling (Kalavagunta et al., 2013). Generally, four different types of fibre reinforced polymers were used in strengthening of structural members such as glass fibre reinforced polymer, carbon fibre reinforced polymer, and aramid fibre reinforced polymer and basalt fibre reinforced polymer. CFRP used as an external strengthening material mainly because of its light weight, high tensile strength, fatigue, seismic 
and corrosion properties (Teng et al., 2012). CFRP strengthened cold formed steel single and built up beams were studied to investigate the strength and behavior (Chakravarthy et al., 2017a;b). Similar research work was carried out on cold formed steel column and beams as listed in the references.

Based on the previous literature it is noted that less number of research work carried out in CFRP strengthened built up beams. This paper reports the results of experimental studies on the CFRP strengthened cold formed steel built up box shaped beams. In these study failure modes, deflections were also observed. The experimental loads were compared with the results of AISI specification.

\section{Materials}

In this experiments three materials were used namely cold formed steel, epoxy resin and carbon fibre reinforced polymer sheets. The cold formed steel section used in this study which was manufactured in roll forming operation into channel shapes in factory and these channel shape sections fabricated to build up box shaped section by joining two channels front to front using screw connection as shown in Fig. 1. The cold formed steel sections used in this experiment were $0.6 \mathrm{~mm}, 0.75 \mathrm{~mm}$ and $1 \mathrm{~mm}$ thick. The sectional properties of built up cold formed steel sections are as shown in Table 1 . The nominal yield strength and modulus of elasticity of cold formed steel sections are $550 \mathrm{~N} / \mathrm{mm}^{2}$ and $2.05 \mathrm{x}$ $10^{5} \mathrm{~N} / \mathrm{mm}^{2}$ respectively. The carbon fibre reinforced polymer sheet available in one roll of $0.5 \mathrm{~m}$ width and $100 \mathrm{~m}$ length which was procured from MAPEI sdn Bhd, Malaysia. The CFRP fabrics were cut according to the size of beams which are $0.167 \mathrm{~mm}$ thickness and nominal tensile strength of $4830 \mathrm{Mpa}$. The MCDur 1209 epoxy resin was used to wrap CFRP on the prepared beam sections. The surface of the cold formed steel beams was cleaned to remove the dust or any other impurities. A uniform layer of epoxy resin layer applied on the prepared surface of the beam section. CFRP fabric cut according to size of beam and wrapped on the prepared surface of the built up beam section as shown in Fig. 2 .

Table 1: Sectional properties of built up sections

\begin{tabular}{ccccc}
\hline \multirow{2}{*}{$\begin{array}{c}\text { Web } \\
(\mathrm{mm})\end{array}$} & \multirow{2}{*}{$\begin{array}{c}\text { Thickness } \\
(\mathrm{mm})\end{array}$} & $\begin{array}{c}\text { Mass } \\
(\mathrm{Kg} / \mathrm{m})\end{array}$ & \multicolumn{2}{c}{$\begin{array}{c}\text { Box shaped beams } \\
\left(\mathrm{mm}^{4}\right)\end{array}$} \\
\cline { 4 - 6 } & & 0.78 & 181268.7 & 48893.05 \\
75 & 0.6 & 0.99 & 224501.2 & 86264.09 \\
75 & 0.75 & 1.3 & 294747.2 & 60348.56 \\
100 & 1 & 1.72 & 737803.7 & 181841.2 \\
\hline
\end{tabular}

\section{Tensile coupon tests}

Tensile coupon tests were performed to determine the true stress-strain properties of cold formed steel and CFRP. The tensile coupon test specimens are as shown in the Fig. 3 and Fig. 4. The cold formed steel tensile test specimens were 0.6 $\mathrm{mm}, 0.75 \mathrm{~mm}$ and $1 \mathrm{~mm}$ thick which were cut into $12.5 \mathrm{~mm}$ width, $200 \mathrm{~mm}$ length with a gauge length of $50 \mathrm{~mm}$ as shown in Fig. 3. The CFRP sheets were $0.167 \mathrm{~mm}$ thick which were cut into $50 \mathrm{~mm}$ width and $250 \mathrm{~mm}$ length as shown in Fig. 4. The section properties of tensile coupon specimens were referred from ASTM $(2003,2010)$ standards. The prepared tensile test specimens were placed vertically in universal testing machine with a capacity of $1000 \mathrm{kN}$ and pre load of $250 \mathrm{~N}$ using test speed of $3 \mathrm{~mm} / \mathrm{min}$. The true stress-strain properties determined from the tensile coupon test are presented in Table 2.

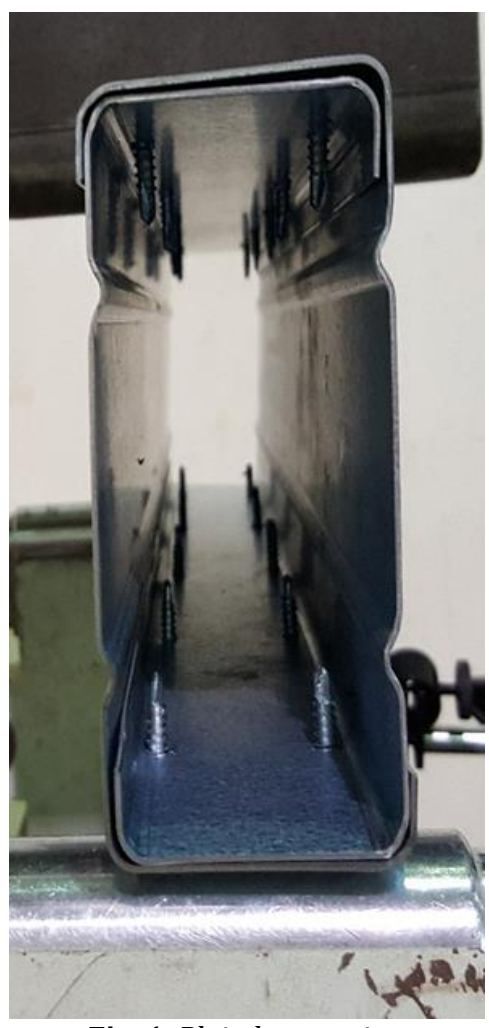

Fig. 1: Plain box section

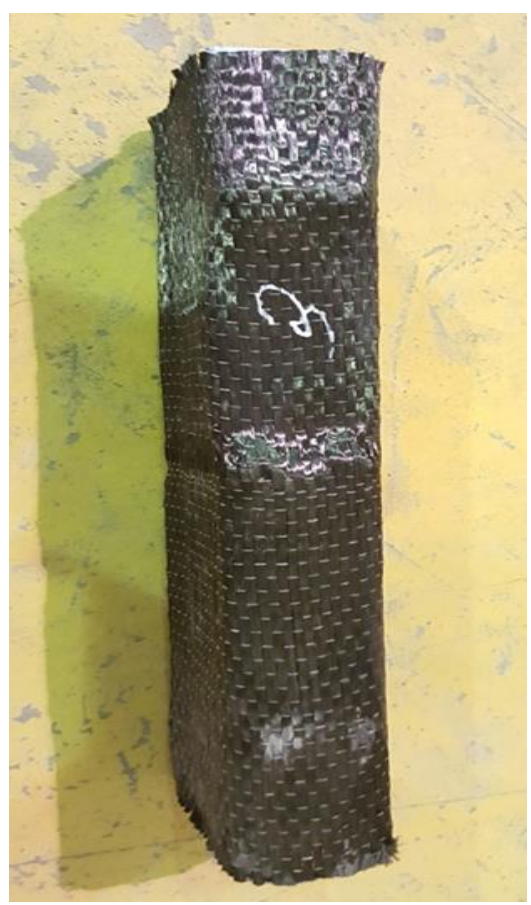

Fig. 2: CFRP wrapped box section 


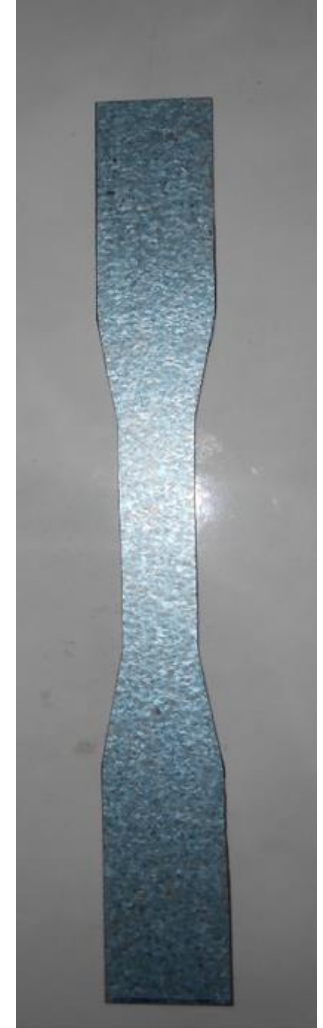

Fig. 3: Cold formed steel

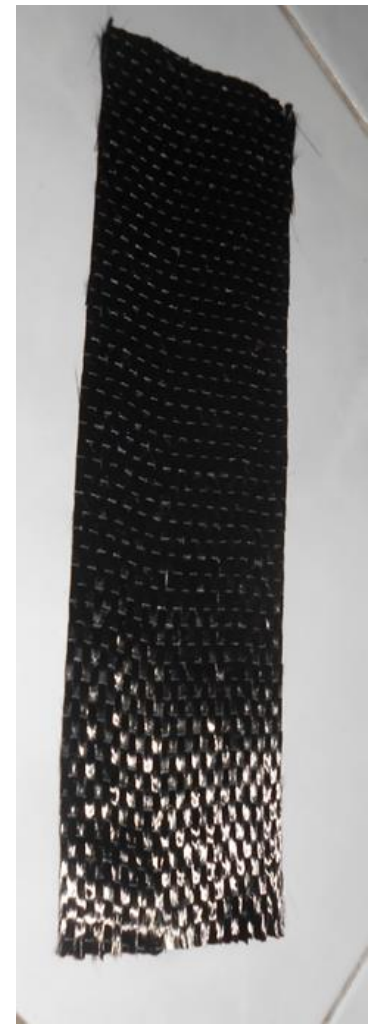

Fig. 4: CFRP

Table 2: True stress-strain properties of cold formed steel

\begin{tabular}{ccccc}
\multicolumn{5}{c}{ and CFRP } \\
\hline & Eo $(\mathrm{MPa})$ & $\sigma_{0.2}(\mathrm{Mpa})$ & $\sigma_{\mathrm{u}}(\mathrm{Mpa})$ & $\epsilon_{\mathrm{u}}(\%)$ \\
\hline Cold formed steel & $2.07 \times 10^{5}$ & 660 & 672.2 & 6.3 \\
CFRP & $2.51 \times 10^{5}$ & 4778 & 4881 & 2.5
\end{tabular}

\section{Test procedure}

The test set up is as shown in the Fig. 5 and Fig. 6. The length of beams was $300 \mathrm{~mm}, 400 \mathrm{~mm}$ and 500 $\mathrm{mm}$. The beams were placed in an adjustable platform in the universal testing machine. The beam specimens were loaded exactly at the centre of the beam specimen in the $300 \mathrm{kN}$ capacity universal testing machine at the rate of $0.1 \mathrm{~mm} / \mathrm{min}$. To determine the deflection of the beam specimen using linear variable differential transformers (LVDT) were attached at the bottom one third and middle span of the test specimen.

\section{Design procedure}

Nominal moment of the beam calculated using the North American standard (AISI, 2007). The calculated moments are presented and compared with experimental results as shown in Table 4.

$\mathrm{Mn}=$ Se.Fy

Se = Elastic section modulus;

Fy $=$ Yield stress of cold formed steel.

$S e=I_{X} / Y_{c p}$

$\mathrm{I}_{\mathrm{x}}=$ Moment of inertia of full unreduced section about $x$ axis normal to web.

$\mathrm{Y}_{\mathrm{cg}}=$ Distance from extreme fiber to neutral axis in $\mathrm{y}$ direction. Allowable moment

$\mathrm{Ma}=\mathrm{Mn} / \Omega \mathrm{b}$

where $\Omega b=1.67$. Maximum allowable point load at mid span:

$$
\begin{aligned}
& \mathrm{Ma}=\mathrm{W} . \mathrm{l} / 4 ; \\
& \mathrm{W}=\mathrm{Ma} .4 / \mathrm{l} .
\end{aligned}
$$

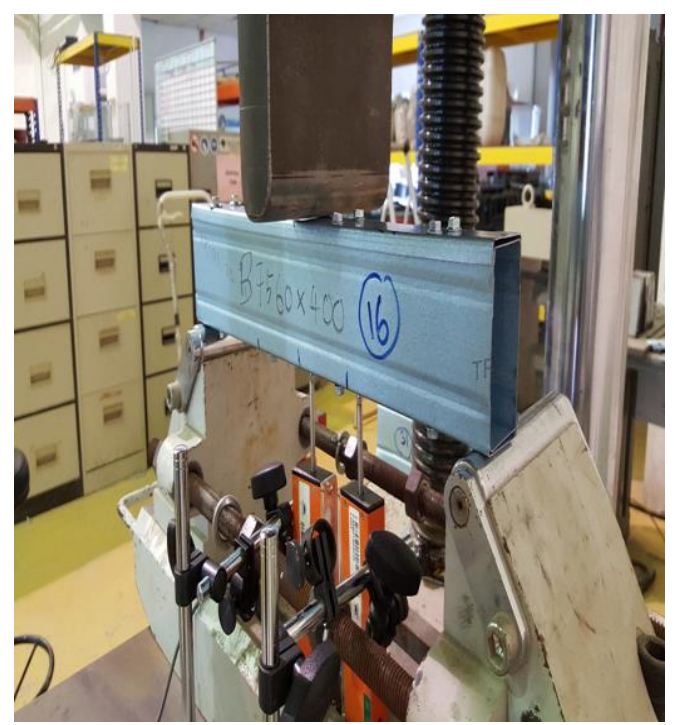

Fig. 5: Single point bending test of plain box section

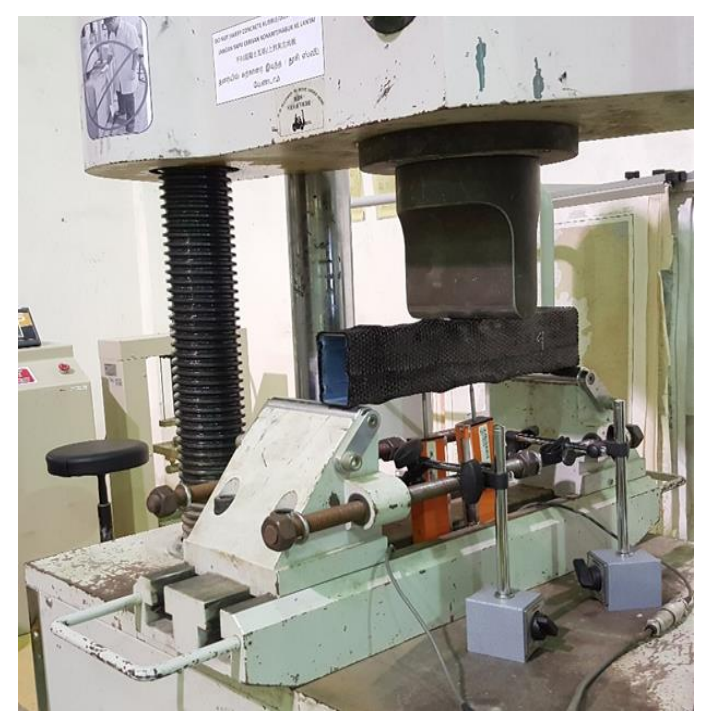

Fig. 6: Single point bending test of CFRP strengthened box section

\section{Results and discussions}

Experimental results show that the load carrying capacity of built up plain and CFRP strengthened beams which are presented in Table 3. Deflection was noted at one third and mid span of the cold formed steel beam as shown in Fig. 7 and Fig. 8. Failure modes were investigated as shown in Fig. 912.

\subsection{Load carrying capacity}

It can observe from Table 3, there is an increase in strength due to CFRP wrapping ranges from $4.67 \%$ to $16.47 \%$. The variation in strength gained due to CFRP wrapping is mainly by complexity 
involved in wrapping of CFRP. The average increase in strength noted as $9.76 \%$. This is expected because CFRP wrapping increases the cross sectional area and strong bond between cold formed steel and CFRP using epoxy resin will increase the strength of the member. The maximum load capacities were calculated based on design guidelines provided by AISI standard.

Maximum load at failure of experimentally tested plain sections were compared with maximum load capacity of AISI specification as shown in Table 4, where the results obtained are in reasonable agreement.

Table 3: Experimental results Plain beam vs CFRP strengthened beams

\begin{tabular}{|c|c|c|c|c|}
\hline \multicolumn{2}{|c|}{ Beam Sections } & Max load on Plain sections (kN) & Max load on CFRP sections (kN) & \% increase \\
\hline B1 & B75x0.6x300 & 5.4 & 5.88 & 8.16 \\
\hline B2 & $\mathrm{B} 75 \times 0.6 \times 400$ & 5.35 & 5.74 & 6.71 \\
\hline B3 & B75x0.6x500 & 4.31 & 5.01 & 13.97 \\
\hline B4 & B $75 \times 0.75 \times 300$ & 8.82 & 10.56 & 16.47 \\
\hline B5 & B $75 \times 0.75 \times 400$ & 8.56 & 9.17 & 6.65 \\
\hline B6 & B $75 \times 0.75 \times 500$ & 8.43 & 8.88 & 5.10 \\
\hline B7 & B75x1x300 & 15.61 & 17.28 & 9.66 \\
\hline B8 & B $75 \times 1 \times 400$ & 15.16 & 16.90 & 10.25 \\
\hline B9 & $\mathrm{B} 75 \times 1 \times 500$ & 13.23 & 16.42 & 19.42 \\
\hline B10 & B100x1x300 & 16.1 & 16.89 & 4.67 \\
\hline B11 & B100x $1 \times 400$ & 16.04 & 16.85 & 4.8 \\
\hline B12 & B100x1x500 & 15.25 & 17.20 & 11.33 \\
\hline & & Mean & & 9.76 \\
\hline
\end{tabular}

Table 4: Experimental results of Plain beam vs AISI standard results

\begin{tabular}{|c|c|c|}
\hline Beam Sections & Max load on Plain sections (kN) & Max load capacity (Resistance) based on AISI standards (kN) \\
\hline B1 $B 75 \times 0.6 \times 300$ & 5.4 & 21.22 \\
\hline B2 $\quad$ B75 $\times 0.6 \times 400$ & 5.35 & 15.91 \\
\hline B3 $\quad$ B75 $\times 0.6 \times 500$ & 4.31 & 12.73 \\
\hline B4 B75x0.75x300 & 8.82 & 26.28 \\
\hline B5 B75x0.75x400 & 8.56 & 19.71 \\
\hline B6 B75x0.75x500 & 8.43 & 15.77 \\
\hline B7 $\quad$ B75x1x300 & 15.61 & 34.51 \\
\hline $\mathrm{B} 75 \times 1 \times 400$ & 15.16 & 25.88 \\
\hline B $75 \times 1 \times 500$ & 13.23 & 20.70 \\
\hline B10 B100x1x300 & 16.1 & 64.79 \\
\hline B11 B100x1x400 & 16.04 & 48.59 \\
\hline B12 B100x1x500 & 15.25 & 38.87 \\
\hline
\end{tabular}

\subsection{Deflection}

Two LVDT are placed at the bottom of the cold formed beam to measure the deflection at one third and mid span of the beam. The maximum deflection at one third spans observed as $6.18 \mathrm{~mm}$ for plain section and $5.39 \mathrm{~mm}$ for CFRP strengthened beam as shown in the Fig. 7. The maximum deflection at mid span position observed as $7.51 \mathrm{~mm}$ for plain section and $5.85 \mathrm{~mm}$ for CFRP strengthened beam as shown in the Fig. 8. The results show that plain sections prone to more deflection compared to CFRP strengthened section. Due to increase in the cross sectional area of the cold formed built up beams leads to decrease in the deflection of the beams. Hence, CFRP strengthening technique is effective in reduction of deflection.

\subsection{Failure modes}

Fig. 9-12 show the failure modes of the cold formed built up box shaped plain and CFRP strengthened beams. Local buckling observed in this cold formed beam sections. The buckling observed mainly at the web of the beam section. Plain section experienced more buckling compared to CFRP strengthened sections. CFRP acts as a stiffener which delays the buckling. The box section was made by joining the two channel sections where flanges are over lapping with one another where no buckling observed. The buckling observed mainly in the web and edges of flanges where no screw connection.

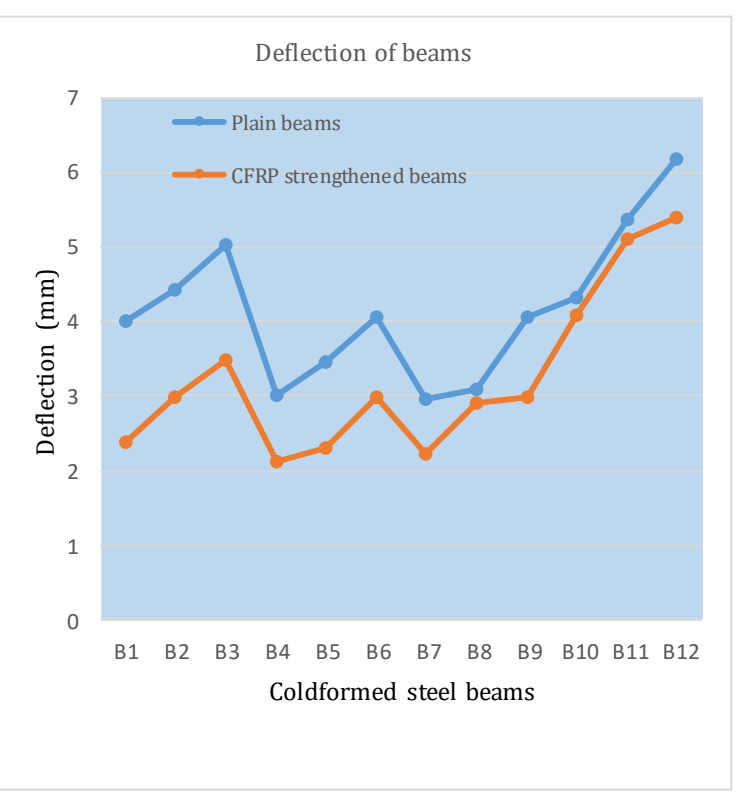

Fig. 7: Deflection at one-third position of beam

\section{Conclusion}

The experimental findings show that external strengthening of CFRP is one of the promising techniques. This investigation shows the average increase of strength up to $9.76 \%$ due to CFRP 
wrapping. The experimental maximum failure load of cold formed built up box sections were compared with AISI specification and experimental test specimens were failed before reaching the maximum theoretical load carrying capacity. Deflection observed at one third and middle span, as expected higher deflection observed at the mid span. Deflection results show that CFRP strengthening plays a significant role in controlling deflection. The cold formed steel box sections failed by local buckling. This type of box shaped sections resistant to torsion hence, no sections fails in torsional buckling. This experimental study concludes that use of CFRP as strengthening agent will enhance the load carrying capacity, reduced deflection and delay in buckling.

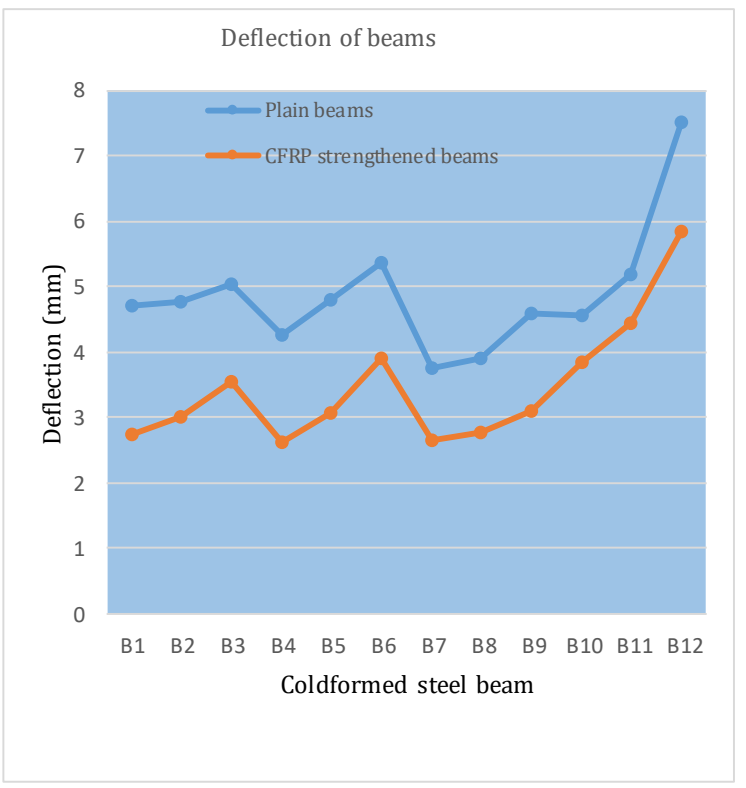

Fig. 8: Deflection at mid position of beam

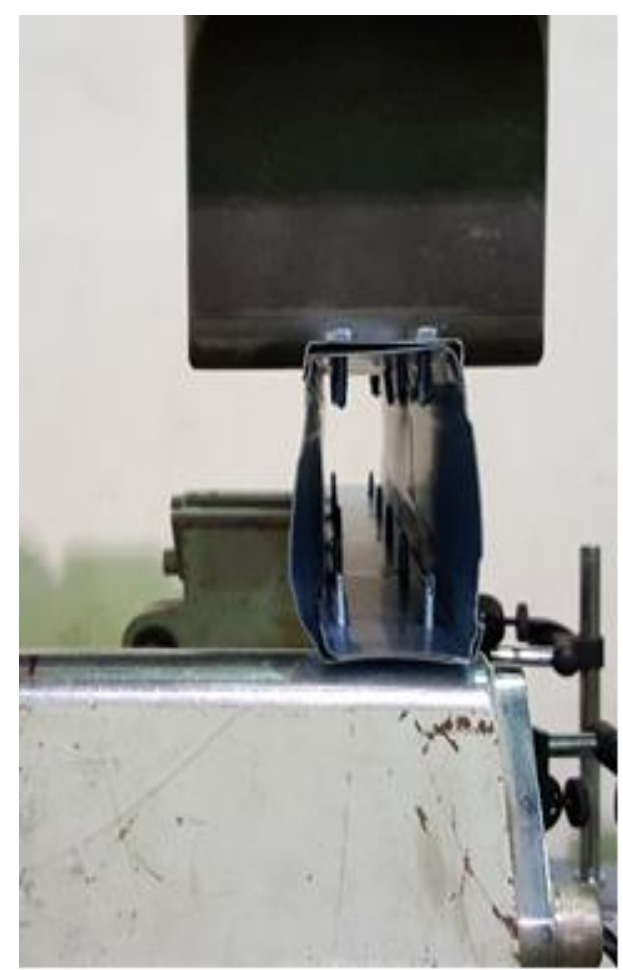

Fig. 9: Local buckling

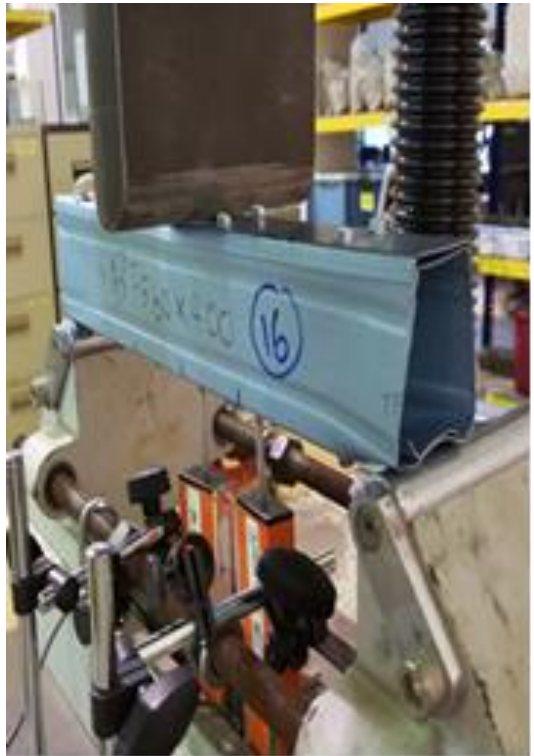

Fig. 10: Local buckling

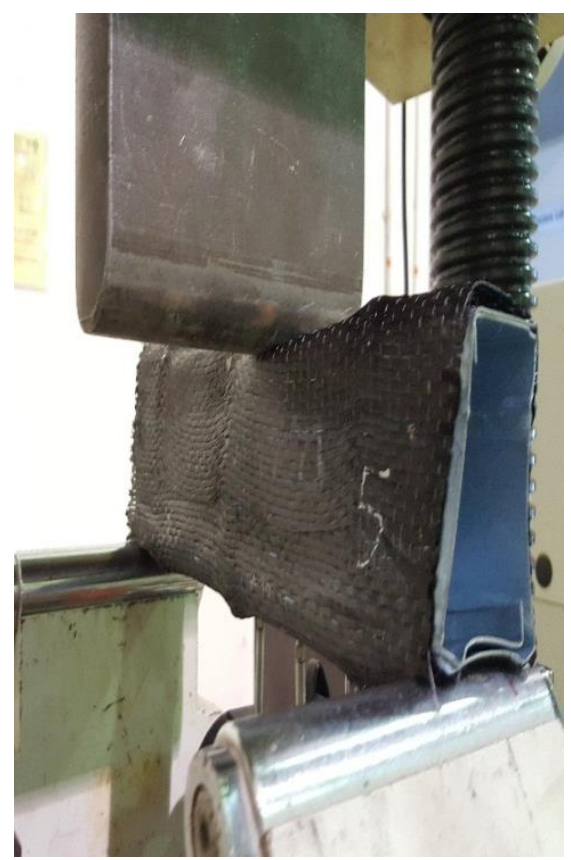

Fig. 11: Local buckling

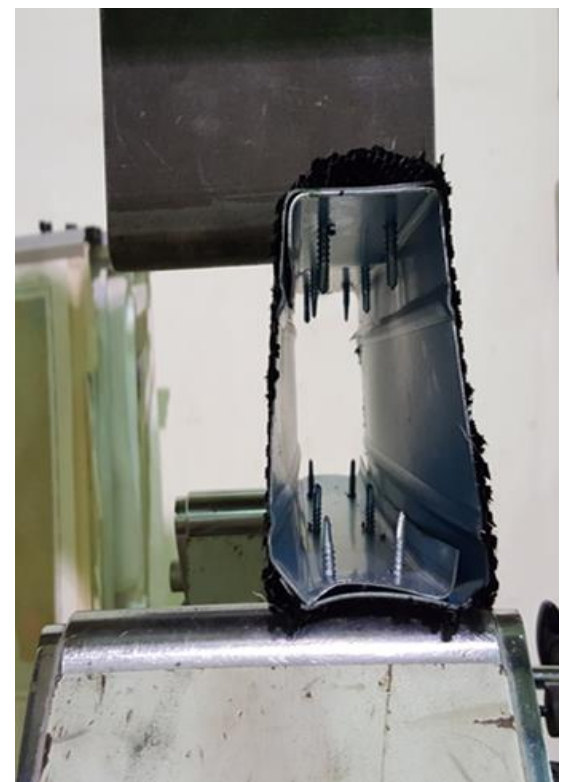

Fig. 12: Local buckling 


\section{Acknowledgement}

We are sincerely thankful to Blue scope Lysaght sdn Bhd, Malaysia for providing cold formed steel sections, MC-Bouwchemie International for supplying epoxy resin (MC-Dur 1209 TX) and laboratory staff of Universiti Tenega Nasional, Malaysia.

\section{References}

AISI (2007). North American specification for the design of coldformed steel structural members. American Iron and Steel Institute, New York, USA.

ASTM (2003). 8M. Standard test methods of tension testing of metallic materials [metric] (ASTM E 8M). Annual book of ASTM standards, American Society for Testing and Materials, West Conshohocken, Pennsylvania, USA.

ASTM (2010). Standard Test Method for Tensile Properties of Thin Plastic Sheeting. American Society for Testing and Materials, West Conshohocken, Pennsylvania, USA.

Chakravarthy N, Naganathan S, Aun JTH, Kalavagunta S, Mustapha KNB, and Veena TR (2017a). Experimental investigation of CFRP strengthened I-shaped cold formed steel beams. Jurnal Teknologi, 79(5): 83-89.

Chakravarthy N, Naganathan S, Bhakri RSAB, Kalavagunta S, Mustapha KNB, and Phalguna HG (2017b). Cost effectiveness of CFRP repair Technique for cold formed steel beams. Indian Journal of Science and Technology, 10(18): 1-7.
Gardner L, Saari N, and Wang F (2010). Comparative experimental study of hot-rolled and cold-formed rectangular hollow sections. Thin-Walled Structures, 48(7): 495-507.

Kalavagunta S, Naganathan S, and Mustapha KNB (2013). Proposal for design rules of axially loaded CFRP strengthened cold formed lipped channel steel sections. Thin-Walled Structures, 72: 14-19.

Kankanamge ND and Mahendran M (2012). Behaviour and design of cold-formed steel beams subject to lateral-torsional buckling at elevated temperatures. Thin-Walled Structures, 61: 213-228.

Macdonald M, Heiyantuduwa MA, and Rhodes J (2008). Recent developments in the design of cold-formed steel members and structures. Thin-Walled Structures, 46(7): 1047-1053.

Silvestre N, Camotim D, and Young B (2009). On the use of the EC3 and AISI specifications to estimate the ultimate load of CFRPstrengthened cold-formed steel lipped channel columns. ThinWalled Structures, 47(10): 1102-1111.

Teng JG, Yu T, and Fernando D (2012). Strengthening of steel structures with fiber-reinforced polymer composites. Journal of Constructional Steel Research, 78: 131-143.

Yu C and Schafer BW (2003). Local buckling tests on cold-formed steel beams. Journal of Structural Engineering, 129(12): 15961606.

Yu C and Schafer BW (2006). Distortional buckling tests on coldformed steel beams. Journal of structural engineering, 132(4): 515-528.

Yu WW (2000). Cold-formed steel design. John Wiley and Sons. Hoboken, New Jersey, USA. 